\title{
Law \& Economics in the Italian Constitutional Jurisprudence: The Case of the Windfall Profit Tax on Energy Companies
}

\author{
${ }^{1}$ Coethe-Universitat Frankfurt am Main, Frankfurt am Main, Hessen, Germany, E-mail: lamorello@llm17.law.harvard.edu \\ ${ }^{2}$ Department of Law, Università degli Studi di Milano-Bicocca, Milan, Italy, E-mail: stefanoronco@msn.com \\ ${ }^{3}$ Harvard Law School, Cambridge, USA, E-mail: lamorello@llm17.law.harvard.edu
}

\begin{abstract}
:
In the judgment issued on 2 February 2015 the Italian Constitutional Court decided upon the constitutional legitimacy of the windfall profit tax imposed by the Italian government in 2008 on profitable energy companies. In his decision the Court disentangles the very economic foundations of such a tax and seeks to explain under its legal reasoning the market outcomes for the energy industry. The aim of this article is to assess the path-breaking law and economics methodology used, for the first time, by the Italian Court to scrutinize the very nature of the tax reform. In doing this, the authors discuss how the Court envisages both a micro and a macro-economic perspective in its analysis which, in turn, shall take into account the primary principles embedded in the Italian Constitution. The newly adopted methodology may entail a change of paradigm in the way the Constitutional Court carries out its own review of constitutionality with respect to domestic provisions with far-reaching economic and budgetary consequences.
\end{abstract}

Keywords: law \& economics, fiscal policy, tax law, constitutional law

DOI: $10.1515 / g j-2016-0016$

\section{Introduction}

In its judgment on 11 February 2015, n. 10, the Italian Constitutional Court declared the unconstitutionality of Art. 81, paragraphs 16, 17 and 18 of Law Decree n. 112/2008, establishing the so-called Robin Tax.

The legal discipline which was subjected to the review of constitutionality provided a surcharge on the ordinary corporate income tax, applicable only to certain operators - broadly speaking, undertakings in the energy sector - and only under certain conditions - revenues and taxable income exceeding certain thresholds. It follows that the entities falling within the scope of application of this legislation were levied at an increased rate - in the form of this surcharge - on their overall income, potentially resulting also from revenues arising out from activities non connected to the energy sector.

This judgment is of considerable interest from a two-folded perspective. ${ }^{1}$ It firstly attracted considerable attention from a strictly Italian constitutional perspective as it derogates from the traditional view by which the decisions of the Constitutional Court which lead to a declaration of unconstitutionality entail a retroactive effect and trigger the right of taxpayers to claim back the amounts unlawfully assessed on its basis. On the contrary, the Court decided to narrow the effects of its decision, limiting the scope of application only to the rights arisen subsequently its publication on the Italian Official Gazette.

Secondly, the judgment at hand raises significant issues from a fiscal policy perspective, as it underlines an innovative interpretation of the recently-constitutionalized principle of a balanced budget expressed in art. 81 of the Italian Constitution. This second aspect will be the exclusive subject of this paper.

In this regard, the aim of this paper is to scrutinize the innovative approach undertaken by the Italian Constitutional Court in its review of constitutionality. In particular, the ruling at stake is characterized by an innovative law and economics analysis that looks at the individual and aggregate effects of such corporate levy as juridical underpinnings against which testing the constitutional legitimacy of the Law Decree.

In light of this new approach, the constitutional interpretation upheld by the Italian Supreme Court sheds new light on the theoretical relationship between some constitutionalized principles and their economic dynamics. Moreover, for the first time ever, the Court seems to explicitly take on a rudimental macro-economic 
analysis of legislative provisions that dwell on the distributive welfare effects that the corporate levy is supposed to produce in the Italian economy as a whole.

The paper is organized as follows: Section 2 describes rationale, features and externalities of the windfall profit tax, as structured by the Italian government. Then, in Section 3, the judgment of the Constitutional Court is examined under a very general legal perspective that seeks to deconstruct the ruling under both its microeconomic and macro-economic dimensions. On the one hand, we attempt to describe how - and to what extent - the microeconomic inefficiencies of the Law Decree are assessed by the Court via a functional cost-benefit analysis. On the other hand, we seek to sketch out the macroeconomic underpinnings that led the Court to declare the constitutional illegitimacy of Art. 81, paragraphs 16, 17 and 18 of Law Decree n. 112/2008. Section 4 concludes.

\section{Constitutional challenges in the 2008 Italian reform establishing a windfall profit tax on energy companies}

\subsection{The windfall profit tax: rationale, content, and externalities}

As briefly introduced before, on 25 June 2006, the Italian government adopted Law Decree n. 112/2008, containing urgent measures for economic development, simplification, competitiveness, the stabilization of public finance and tax equalization. Within this piece of legislation - specifically in Art. 81, paragraphs 16-18 - the Italian legislator introduced a permanent corporate income tax surcharge for companies carrying out their main activities in one of the these fields: research and exploitation of hydrocarbons; production and sale of electricity; natural gas transportation and distribution; oil refining and production and trading of petrol, gasoline, lubricants, liquefied gas of petrol and natural gas.

The tax rate and tax base of this surcharge changed several times subsequently its introduction. It was originally imposed at a rate of $5.5 \%$ and applied to resident companies and permanent establishment of non-resident undertakings operating in the aforementioned sectors with revenues over $€ 25$ million. ${ }^{2}$ In addition, it should be recalled that by virtue of Law Decree n. 101/2013, it was provided that any recharge of the surcharge at hand to the final customers in terms of higher retail prices should be considered unlawful.

As it was underlined in doctrinal studies, ${ }^{3}$ the rationale of this legislation should be envisaged in decision of the Government to set up a levy equivalent to the surplus revenue obtained by the operators in the energy sector as a consequence of the particular economic conjuncture. In other words, the goal of the surcharge was to levy at a higher rate those undertakings whose profits were strongly linked from the sales of fossil fuels that -given the condition of the international markets - had reached high prices.

As a consequence, the Italian legislator deemed that those revenue should be considered windfall profits, derived from opportunistic and speculative market operations, consisting, in particular, in the exploitation of upward fluctuations in the prices of commodities, as a way to increase the prices of downstream products, but without lowering the resale price to consumers as soon as the price of raw materials was decreasing. ${ }^{4}$

Such a rationale involves the complex problem relating to the significance of the element of risk as a typical condition of the entrepreneurial activity. This is a widely-known topic in corporate law studies, where it has been recognized that the element of risk represents a corollary of the notion of economic activity and constitutes a prerequisite for the qualification of the notion of entrepreneur. ${ }^{5}$ In particular, it is acknowledged that for carrying out an analysis of the notion of business income with reference to the element of economic risk it is required to distinguish business income in three different elements: "at the bottom line the risk-free rate of return on the invested capital, secondly infra-marginal income from economic rents (eg from location-specific natural resources, from proprietary intellectual property or from other monopolistic income-generating assets) and - last but not least - income from risky activities, where the income is dependent on uncertain future developments like the success of innovative research, the exploitation of a new market, the reliability of the existing workforce or the stability of the political environment". ${ }^{6}$

Therefore, according to this theoretic framework, it would not be possible to identify a unitary notion of business income, being necessary to differentiate business income on the basis of the higher or lower kind of risk of the activity which is from time to time carried out.

As a consequence, it would be legitimate to justify a diversified levy that takes into account the specific degree of economic risk involved. This line of reasoning, in particular, is shared by those doctrinal positions that, assuming the existence of such a diversified gradient of risk that characterizes and encompasses the category of business income, affirm the legitimacy of forms of taxation specifically aimed at levying at a higher rate those windfall profits deriving from business activities. 
It is held that these profits derive from monopolistic rents linked - for example - to legislative provisions and regulations that attribute only to a selected number of undertakings certain rights and permissions by law, or related to contingent market conditions that allow some industrial enterprises to exploit their dominance on the market by generating excessive profits unrelated to any business risk. ${ }^{7}$

In this regard, it should be noted that the levy of taxes aimed at targeting windfall profits is not un common. A well-known case is represented by the U.S. Crude Oil Windfall Profit Tax Act, which was introduced in 1980 and subsequently repealed in 1988. This levy was aimed at neutralizing the excessive profits determined by undertakings operating in the oil sector as a result of the deregulation of oil prices. ${ }^{8}$

However, it is interesting to focus on a more recent example of windfall profit tax scheme, whose compatibility with the legislation of the European Union was recently decided by the Court of Justice of the European Union (hereinafter 'Court of Justice'). In particular, the Court of Justices stated in the Iberdrola case that levies adopted by Member States and specifically designed in order to target windfall profits could be considered, in principle, as measures in conformity with the Treaties and the secondary legislation of the European Union. ${ }^{9}$

In this regard, the Court of Justice held that no violation occurred with reference to the tax scheme adopted by the Spain government that aimed at limiting the benefits accrued to undertakings operating in the sector of production of electricity that had received from the State, free of charge, environmental emission rights freely tradable and transferable to third parties. ${ }^{10}$

In this judgment the Court of Justice affirmed to be in conformity with European Union law those national provisions "under which the remuneration for electricity producers is to be reduced in order to counterbalance windfall profits resulting from the allocation of emission allowances free of charge [...]". ${ }^{11}$

From the above, it follows that the Court of Justice has recognized the validity of tax legislations - even when significantly hit the taxpayer as it was demonstrated in the Iberdrola case - provided that the levy at hand would be shaped in a way that ensures that the windfall profit is clearly distinguished from other profits generated by the undertaking, whose taxation should not be subjected to any higher surcharge.

\subsection{The Italian experience in view of the constitutional judgment}

With the mentioned decision, the Constitutional Court declared the Robin tax unconstitutional as it violated the constitutional principles, enshrined in the Italian Constitution in Artt. 3 and 53, of equality and ability to pay. The path taken by the Court to undertake the review of constitutionality is marked in the following way.

The Court, firstly, highlights that the rationale of the Robin tax was to carry out a kind of 'qualitative discrimination' between different forms of business income, whose tax rate should be differentiated even if, from a quantitative perspective, the amount of wealth would be the same. In other words, the Court assesses whether it would be constitutionally legitimate to tax differently the same amount of income whereas it expresses a different ability to pay on the part of the taxpayer. ${ }^{12}$

Then, the judgment goes on recognizing that the tax surcharge was inspired by the goal of discriminating the income produced by undertaking in the energy sector and identifies possible justifications for such surcharge. In particular, the Court highlights the fact that those entities carry out activities within an industry with very high profitability, low-competition and inelastic demand. It, therefore, qualifies those profits as windfall profits, dependent upon circumstances and economic factors of random nature, unrelated from effective activities and investment choices of the taxpayer.

Against this background, the analysis of the Court focuses on the proportionality principle, assessing whether the Robin tax represents a proportionate mean chosen by the legislator. In this regard, the answer of the Court is negative, highlighting three issues that determine the unconstitutionality of the legislation.

On the one hand, the Court notes that the surcharge was imposed on the overall taxable income, without levying only the share of allegedly windfall profits related to the energetic activities. On the other hand, the Court affirms that the introduction of the surcharge was legitimate only in so far as the economic conjuncture was able to actually produce windfall profits on the part of the undertaking. However, as a consequence of the fact that such an economic situation had recently changed, the levy of the surcharge did not reflect the current ability to pay of the same energy companies. Finally, the Court underlines that a third flaw of the tax relates to the impossibility of adopting tools able to avoid that the surcharge is actually translated to final customers by way of increased retail prices.

After having held the unconstitutionality of the Robin tax, the Court focuses on the temporal limitation of the effects of its decision. In this regard, the Court states that the indiscriminate application of its decision with retroactive effect, allowing every taxpayer to claim back what already paid, would likely affect other constitutional values, as budgetary concerns - explicitly taken into account in the newly-enacted art. 81 of the Italian Constitution $^{13}$ - would arise given that the surcharge at hand constituted an important share of the Italian overall internal revenue. 
As a consequence, the Court holds that the temporal effects of its judgment should take place following the publication of the judgment itself on the national Official Gazette, therefore denying the repayment of the sums unduly levied up to that moment. ${ }^{14}$

\subsection{Reasoning of the Court and its declaration of illegitimacy}

The latter point, related, to the relevance of budgetary constraints as constitutional values able to determine a limitation of the temporal scope of application of the decision of the Court is a significant affirmation and represents a new development, whose impact on the review of constitutionality of Italian provisions with budgetary consequences could be far-reaching. In particular, the analysis undertaken by the Court - which will be fully assessed in Section 3 - weights, from a fiscal policy point of view, on the financial consequences that could flow from a declaration of unconstitutionality that would not set a temporal limit, allowing taxpayers to claim back sums already levied on the basis of the unlawful surcharge.

In light of these considerations, the Court evaluates that the total repayment of the unconstitutional surcharge would result in a financial outflow from the State, which, as a consequence, would violate the balanced budget provision enshrined in art. 81 of the Constitution.

This conclusion is reinforced given that, had the tax unlawfully levied been refunded, the fiscal balance should be achieved only at the cost of a new budgetary measure which would affect the economically weaker sectors of society. Therefore, weighing the interests of both groups of interests - the levied taxpayers and the weaker members of the Italian population - the Court considers that the effect of the Robin tax should not have a retroactive effect. ${ }^{15}$

\section{Deconstructing the judgement: a law economics analysis}

The theoretical debate upon the introduction of a methodology for a law and economics assessment of constitutional principles has enjoyed wide, positive reception in the academia, especially in common law countries. ${ }^{16}$ In the last years a well-found economic approach to constitutional provisions paved the way for reconsidering the relationship between the legal settings of state institutions and the economic underpinnings underlying their rationale. As a result of this newly-established constitutional law and economics framework, many constitutional and supreme courts come out from time to time with judicial reviews of legislations that take into account the economic rationale of legal phenomena, thereby shedding new light upon the use of economic analysis "as an overarching guide to constitutional interpretation". ${ }^{17}$

The content of the judgment at stake is surprisingly important for such a debate. In fact, the reasoning undertaken the Italian Constitutional Court not only fully falls within such a consolidated law and economics scholarship, but it also seems to enlarge the scope of the mainstream law and economics analysis by undertaking - for the first time ever - a concise "macroeconomic" approach to taxation law. Hence, the decision of the Court has a twofold nature: (i) a micro-economic dimension upon which the declaration of unconstitutionality is founded; and (ii) a macro-economic dimension that justifies the pronunciation in favor of the denial to pay back the sums unduly levied up by the Italian government.

In light of these two core arguments, the aim of the next paragraphs is to give account of both the microand macro-standpoints characterizing the court's sentence.

\subsection{The micro-economic dimension: inefficiency and discriminatory outcomes of the tax}

Paraphrasing Drapkin and Verleger (1981), the economic rationale of introducing a windfall profit tax lies into the government's efforts to redistribute the extra domestic production income attributable to the exercise of oligopolistic pricing power by energy companies. ${ }^{18}$ This tax is meant to prevent the full transfer of income from consumers to producers when extra profits are generated for exogenous reasons while, at the same time, bringing domestic prices to world levels. ${ }^{19}$

In this way the tax charge is thought to affect those markets which are supposedly not competitive on their own and where large profits earned by companies induce little changes on the supply side and are largely unanticipated and unreasonable. ${ }^{20}$ As no additional cost or effort has been incurred to generate these extra profits which, in turn, are solely due to changes in market prices, restricting the magnitude of such extra income which ultimately harm consumers is generally considered morally justified. ${ }^{21}$ The rationale of the government intervention therefore is to be found somehow into a principle of "economic equity or fairness", ${ }^{22}$ where the windfall profit tax aims at primarily redistributing wealth from oligopolistic producers to consumers. ${ }^{23}$ 
Although the rationale of the government intervention is clearly comprehensible from a public policy perspective, ${ }^{24}$ the economic literature has scrutinized in details the downside externalities associated to such an income tax. ${ }^{25}$ As this tax levy is intended to correct market distortions generated by oligopolistic markets, the economic literature has generally discussed whether - and to what extent - it is appropriate in doing so. Since these externalities are defined in terms of costs that energy producers are required to bear, the microeconomic analysis shall assess whether the benefits generated by "economic equity" are outweighed by the externality costs.

Summing up, it is well recognized that these costs are primarily related to the "second order" distortions these windfall tax charges are capable to produce on the same market.

First, this levy is frequently recognized to reduce production. ${ }^{26} \mathrm{In}$ fact, since energy producers are supposed to be "price takers" selling at world market prices, they are not capable to pass these extra costs to consumers and, therefore, have to absorb them on their own. ${ }^{27}$ As a result of the raising marginal cost of production, the production quantity goes down for any given level of price. ${ }^{28}$ The cumulative deadweight losses occurred are the opportunity cost of the tax charge which in the long-run - if the levy is not restrained for a temporary period only - may be quite substantial. ${ }^{29}$

Second, the lower production along with the imbursement of the new tax charges, is understood to negatively influence corporate earnings. The resulting lower dividend payouts for shareholders reduce stock prices of energy companies, showing up the opportunity costs of shareholders that instead could have opted for different more profitable investments. ${ }^{30}$

However, although the aggregate opportunity costs of above may be considerable, the microeconomic analysis shall nonetheless gauge the volume of the aggregate benefits the income redistribution may determine. ${ }^{31}$ If the deadweight losses are outweighed by individual welfare gains of the government intervention, the windfall profit tax is to be considered not only economic reasonable but also desirable, as it would make the society as a whole better off. ${ }^{32}$ This assessment needs to be made on a case by case basis and shall take into account the technical provisions laid down by the government to construct the content of such a levy. And it is exactly at this juncture that the microeconomic analysis of the Italian Constitutional Court begins.

As a premise of their arguments, the Italian judges seek to disentangle and expose the true nature of the levy introduced by the Law Decree n. 112/2008. They notice in particular the tax charge, as laid down by the Government, is not just circumscribed to the extra-profits generated by sharp increases in oil prices but it is calculated based on the overall taxable income of energy companies irrespective of any price change. The Italian windfall profit tax, therefore, results in a income surtax for firms operating in the energy sector. This statement on the very nature of the tax charge is then reinforced by the failure of the Law Decree to identify any time limit for the application of the law.

In this way the legislator has neglected the provisional nature of such redistributive intervention which, by its very nature, should be limited to those periods characterized by a dramatic increase in oil prices, with energy companies making abnormal and unreasonable profits. ${ }^{33}$ Hence, the Court acknowledges this surtax is not a temporary measure issued under emergency contingencies but it represents a structural measure that the government utilizes to get additional resources from certain targeted producers irrespective of any market circumstance. $^{34}$

In light of this, the Law Decree implicitly introduces a factual discrimination between companies belonging to the energy sector and companies not belonging to it. Certainly, special treatments in taxation law leading to factual discriminations are not unconstitutional per se. ${ }^{35}$ However, to be legally justifiable, not only they shall serve a legitimate economic purpose sought by the legislators, but they shall also be proportionate and reasonable in light of the tax policy outcomes. ${ }^{36}$ Against this backdrop, the critical question for the Court is now whether the surtax is sufficiently proportionate and reasonable under a microeconomic standpoint to meet the rationale of "economic equality" underlying the government redistributive mandate. ${ }^{37}$ Not surprisingly, as argued next, the answer is negative.

As argued by the Court itself, the adoption of such income surcharge fails to achieve the solidarity effects of a proper redistribution. Although the Law Decree forbids energy companies to pass the new levy costs to consumers, ${ }^{38}$ the legislative outcome is, in practice, very different. These costs in fact are ultimately borne by consumers since this tax, as a structural measure, is presumed to increase in the long run the marginal costs and is not restrained in its application by any time limit that may preclude such upward price move. As such, the introduction of this distorted windfall profit tax comes at the cost of eventually harming general consumers, thereby contradicting the microeconomic significance of the equality principle. ${ }^{39}$

Summing up, the Court logically argues the tax charge has no redistributive benefits or welfareimprovement effects that may reasonably outweigh the deadweight losses determined by its application. Additionally, further costs on consumers are underway as this structural measure would eventually lead to higher prices in a market characterized by the inelasticity of demand. ${ }^{40}$ 
In recognizing all of this the Court discloses the unreasonableness and the unfairness of the tax measure. However, the Judges take one step forward in their reasoning. In fact, after careful considering the unconstitutionality of the tax provision, the right of tax refund becomes a fruitful argument to be analyzed under a newly established "law and macroeconomic" perspective.

\subsection{The macro-economic dimension: the right of tax refund and the principle of government budgetary balance}

The relationship between macroeconomics and law is not as straightforward as it could be expected. It is, however, well-known that when legal scholars and practitioners deal with economic concepts and analytical tools, they usually undertake a micro-economic approach to their analysis. ${ }^{41}$

This is due to a number of reasons, among which the complexity in understanding macro models, the difficulty in explaining the related concepts in legal terms, and the lack of proper analytical methodologies are just the most palpable. ${ }^{42}$ Besides this, there is also a shared opinion among lawyers that macroeconomics is not that relevant for the resolution of judicial disputes. ${ }^{43}$ In fact, while micro-economic teachings can be exploited to tackle a wide variety of relevant issues in multiple legal fields, such as antitrust, corporate law, and financial regulation, the same does not seem to hold true for macroeconomics.

Despite early attempts to conceptualize the role of law in addressing aggregate phenomena, ${ }^{44}$ few studies have formalized a relationship between macroeconomic policy and legal reasoning for dispute resolution purposes. However, the recent events occurring in Europe have shaken up considerably this traditional standpoint, shedding new light on the relationship between law and macroeconomics. This has been due mainly to the introduction of several macroeconomic principles into the primary law of the EU and into the constitutional charts of the EU member States.

Through an expansionary process of juridification ${ }^{45}$ a plethora of macroeconomic concepts, such as price stability, financial stability, and fiscal balance have found their own way into legal frameworks worldwide, while lawyers have started to appreciate the criticalities arising from the explanation of their normative content. ${ }^{46}$ These newly-established macroeconomic provisions have challenged the orthodox legal scholarship in a number of ways, the most critical of which is, according to some authors, ${ }^{47}$ the problem of interpretation.

As most of the macroeconomic principles now embedded into primary laws have never been litigated, this problem of interpretation becomes even stronger because of the high degree of indeterminacy featuring their legal meanings which, in turn, may result difficult to apply into concrete cases. In addition, these macroeconomic principles so constitutionalized are to be balanced with other fundamental provisions of different nature, whose application alone would provide different outcomes in terms of interpretation and resolution of the disputes at stake.

It is against this backdrop that the judgment of the Italian Constitutional Court paves the way for a new macro-economic analysis of constitutional law. By widening the normative content of article 81 of the Italian Constitution - which lays down, as mentioned above - the principle of budgetary balance - the Italian Constitutional Court justifies its stance on rejecting any tax refund in light of the negative aggregate costs and macroeconomic imbalances that a contrary ruling would otherwise generate.

First, a judgment in favor of a tax refund would pose a threat to the fiscal equilibrium of the State balance sheet, thereby endangering the Government's capability to assume its budgetary responsibility and carry on its fiscal policy smoothly. The budgetary disequilibria thus determined would be particularly worrisome when looking at the capacity of the State to service its own outstanding debt in the aftermath of the tax repayment. ${ }^{48}$ Since the sustainability of public debt is interpreted by the Court as a primary obligation the government has to secure in view of the fiscal equilibrium principle, a legal decision that would negatively affect its debt repayment capacity is deemed to encroach upon the very macroeconomic foundations of the Constitution. ${ }^{49}$

In other words, the judgment of the Court is economically justified in view of the possible spillover effects that a tax refund of this nature may bring about on public finances. As shocks to the variables that affect the quantity and value of outstanding debt directly influence future financial costs for sovereigns, a tax refund of such an amount would negatively affect the public balance sheet, and thus, in the eyes of international investors, the government's credibility to meet its obligations. ${ }^{50}$ This would eventually imply higher volatility for sovereign bonds, as the government would find it more difficult now to refinance its debt exposures. ${ }^{51}$ But the higher this volatility, the greater the risk of financial instability, the higher is the cost for the whole national economy. ${ }^{52}$

Second, the Court acknowledges that the imbursement of the tax refund would require the government to take on an additional fiscal maneuver as to guarantee the stability of public finance. 
On one side, this fiscal adjustment would be necessary because of the principle of budgetary responsibility constitutionalized, as argued above, into article 81 of the Constitution. If fiscal stability is in danger, the government has the obligation to exert every effort in order to ease any such risk.

In this context, additional measures to rebalance the public finances of the State would be inescapable. On the other side, the fiscal adjustment would be required, more widely, as to comply with the convergence criteria originally laid down by the Maastricht Treaty, ${ }^{53}$ which set the stage for the European Monetary Union and constituted the pillars upon which the EU macroeconomic constitution was erected. ${ }^{54}$

Although the enforcement mechanism for countries failing to meet these requirements has never led to any real sanction, ${ }^{55}$ the Maastricht limits on government debt and budget deficit are nonetheless binding reference values for public spending of EU member States. The convergence criteria are, therefore, instruments that should inform the fiscal policy of national governments so as to guarantee the maintenance of a sound budgetary discipline. ${ }^{56}$ Accordingly, as for the case of fiscal equilibrium, the normative content of budgetary discipline is deemed as hierarchically superior with respect to the rights of private actors. And as it is strictly necessary for purposes of public good, the public commitment to a sound budgetary discipline leads the Constitutional Court to sacrifice the right of tax refund.

Third, the macroeconomic assessment of the Constitutional Court ends up by looking at the distributional effects that any such tax refund would produce into the Italian economy. In particular, the Constitutional Court sketches out a welfare economics analysis ${ }^{57}$ where the optimality of the refund denial is a function of the distribution of wealth among private actors. Paraphrasing the Court, the economic consequences deriving from the admittance of such a tax refund in times of financial distress would produce an unreasonable wealth redistribution at the expense of the low income classes. Since the latter were the ones more severely hit by the financial burst and its related spillovers, ${ }^{58}$ forcing the government at this stage of the economic cycle to carry on a wealth transfer that excludes these classes is seen by the Judges as irrational.

This wealth transfer in fact would make better off only those market players which have had the possibility to gain extra profits because of the peculiar economic juncture of the energy market. As a result, the raising level of income inequality would finally harm the solidarity expectations of economic agents in these times of crisis, ${ }^{59}$ while the unintended consequence of such irrational wealth allocation would ultimately trigger a lower output growth. ${ }^{60}$

\subsection{Rethinking the relationship between constitutional law, economics and fiscal policy}

The functional law and economics approach featured in the judgment of the Italian Constitutional Court leads us to re-think the relationship between constitutional law, economic phenomena and budgetary policy.

The implementation of micro and macro-economic principles into the constitutional chart, along with the newly associated constitutional scrutiny, somehow discloses a new field of research that requires further investigation.

Thus far, the Italian constitutional doctrine has been rather reluctant to place its legal analysis within a consistent economic framework. ${ }^{61}$ On one hand, the primacy of constitutional norms has been affirmed mostly often without considering the microeconomic externalities and the macro distributional effects that the same provisions could entail. ${ }^{62}$ On the other hand, the constitutional legitimacy of legislative acts by no means has been grounded on the market outcome of their implementation.

Against this backdrop, the aim of this paper is to argue that this judgment could mark a real turning point for both constitutional doctrine and the case-law. ${ }^{63}$ This is not only true with reference to the Italian constitutional dialogue, but it could also provide additional insights for courts of other Member States, as the law and economics analysis characterizing the judgment of the Italian Constitutional Court constitutes a path-breaking analytical paradigm for a constitutional review based on the interplay between the constitutional foundations of the State and the expected (micro and macro) economic utility of its legislative acts.

That said, the principle of budgetary responsibility is not only deemed as the macroeconomic backstop aimed to constrain excessive public expenditures, but it also represents the basic premise upon which economic interactions in the market are settled. In view of this, the case of the Italian windfall profit tax becomes a fruitful experiment to challenge this new analytical approach in the field of fiscal policy.

As it was previously noted, this levy - to be constitutionally legitimate - should not only be consistent with the microeconomic notion of "economic equality" between market participants, thereby preserving the meaning of competitive fairness and consumer protection, but it should also not endanger the macroeconomic objective of budgetary equilibrium pursued by government in accordance with the Constitution.

In this perspective, the content of the law should not harm the solidarity expectations of economic agents, whilst the distributional effects of its implementation should not produce an unreasonable wealth redistribution at the expense of the poorest. 
In the end, the analysis of the above reveals a new challenge for practitioners and judges alike. Both of them are now required to expand the scope of their legal education, as they can no longer neglect the economic underpinnings of the legal provisions they are applying and interpreting. ${ }^{64}$

Due to this, it is advocated that a deeper insight into the fields of micro and macro-economics is needed, as this close interrelationship between law and economics, as well as public policy, is going to be reflected more and more in newly-enacted legal provisions both at the EU and domestic level.

In particular, the juridification of macroeconomics, as a phenomenon currently underway, will require practitioners and judges to gauge the legitimacy of legal acts by analyzing the distributional consequences and the aggregate outcomes of their prescriptive contents.

\section{Conclusions}

The aim of this paper was to describe the change of perspective in the review of legitimacy of the Italian Constitutional Court.

We highlighted that the judgment rendered by the Court on the legitimacy of Art. 81, paragraphs 16, 17 and 18 of Law Decree n. 112/2008 presents an innovative path towards the formalization of an economic analysis of constitutional law.

By scrutinizing the provisions of the Law Decree n. 112/2008 in view of microeconomic and macroeconomic principles recently-enshrined in the Italian Constitutional Chart, the Court pursues an analysis that takes into high consideration the economic dynamics and the aggregate effects of such a fiscal intervention in light of the competitive effects for the market at stake, the related higher costs for consumers and the following deadweight losses for energy companies.

As a corollary of this, the macroeconomic principles of budgetary responsibility and fiscal equilibrium are the constitutional premises that make possible the setting up of a macroeconomic analysis of the levy in terms of wealth redistribution, market expectations and other aggregate outcomes.

Although this law and economics analysis does not represent a novelty for the academic environment, it certainly constitutes a new field of research for practitioners dealing with constitutional issues and more generally, public policy. And, even more important, this judgment seems to be a real challenge for lawyers that now are required to grasp a general understanding of both micro and macroeconomics. This is because the future path of the legal developments is intertwined to the economic functions they are supposed to serve. Hence, the legal provisions become instrumental to the economic outcomes desired by policy-makers. As a result, the constitutional interpretation of the law should no longer neglect the economics underlying its operationalization.

In this perspective, the constitutional ruling on the windfall profit tax rendered by the Italian Constitutional Court certainly seems to fall within this new theoretical course, and, in this way, constitutes a turning point in the discussions related to the interferences between law, economics and public policy.

\section{Notes}

\footnotetext{
${ }^{1}$ This paper is a joint effort of the Authors. For the attribution of paragraphs, Luca Amorello wrote paragraphs 3 and 4 , while Stefano Maria Ronco wrote paragraphs 1 and 2. This judgment has raised significant interest in the Italian doctrine. For an account of the tax issues related to this decision see D. Stevanato (2015), Robin Hood Tax tra incostituzionalità e aperture della Corte a discriminazioni qualitative dei redditi societari, in Corr. trib.,pp. 951 ss.; A. Marcheselli (2015), La incostituzionalità 'retroattiva' della 'Robin Tax': tra violazione dei diritti fondamentali, giurisprudenza evolutiva e conflitti giurisdizionali, in GT-Rivista di Giurisprudenza tributaria, pp. 617 ss.; F. Campodonico (2015), 'Robin Hood Tax': la Corte costituzionale fa chiarezza sui criteri di determinazione della ragionevolezza del tributo, in Dir. prat. trib., II, pp. 436 ss.; A. Mastroberti (2015), 'Robin Hood Tax' illegittima, irragionevole e mal strutturata, ma solo a decorrere dal futuro, in Il Fisco, pp. 866 ss.; P. BORIA (2015), L'illegittimità costituzionale della 'Robin Hood Tax'. E l'enunciazione di alcuni principi informatori del sistema di finanza pubblica, in GT-Rivista di Giurisprudenza Tributaria, pp. 388 ss.

For an account of the constitutional issues related to this judgment see M. Pieroni, O. Porchia (2012), L'obbligo di pareggio di bilancio nel diritto dell'Unione europea: l'introduzione del principio nella Carta costituzionale, in www.cortecostituzionale.it.

${ }^{2}$ The most important modifications were firstly introduced by virtue of Art. 7, paragraph 1 of the Law Decree n. 138/2011 and then with Art. 5 of Law Decree 69/2013. On the basis of these provisions the rate of the tax surcharge was temporarily increased to $10.5 \%$ and the tax base broadened including undertakings and permanent establishment with revenues over $€ 1$ million and taxable income over $€ 300,000$.

Therefore, the overall tax rate - encompassing both the ordinary corporate tax rate of $27.5 \%$ and the surcharge rate of $10.5 \%$ applicable from the fiscal year 2011 - amounted to $38 \%$.

${ }^{3}$ AA.VV. (2013), Analisi giuridica ed economica della c.d. 'Robin tax'. Genesi, attualità e prospettive. G. Visentini, L. Salvini, F. Marchetti (Eds.), Fondazione Bruno Visentini, pp. 2 ss.

${ }^{4}$ Ibidem, p. 4.

${ }^{5}$ See P. Mäntysaari (2010), The law of corporate finance: general principles and EU law. Volume I: cash flow, risk, agency, information, Springer; I. Welch (2009), Corporate finance: an introduction, Prentice Hall.
} 
${ }^{6}$ W. Schön (2014), International taxation of risk, p. 2, available at http://ssrn.com/abstract=2402612. See also D. Shaviro, The economics of tax law, 2014,available at http://ssrn.com/abstract=2380898.

${ }^{7}$ C. Hurt (2009), The windfall myth, available at http:/ /ssrn.com/abstract=1456466; D.P. Rodrìguez (2014), Absorbing EU ETS windfall profits and the principle of free allowances: Iberdrola and others, in Common Market Law Review, pp. 679 ss.

${ }^{8}$ For further analysis on the U.S. Crude Oil Windfall Profit Tax Act, see the General explanation del Crude oil windfall profit tax act of 1980, prepared by the Joint Committee on Taxation of the U.S. Congress, available at http://www.jct.gov/s-1-81.pdf. See also: E. Kades (1999). Windfalls. The Yale Law Journal 108:1546-1552.

${ }^{9}$ Proceeding of the Court of Justice, cases C-566/11, C-567/11, C-580/11, C-591/11, C-620/11, C-640/11.

${ }^{10}$ On this judgment see D.P. Rodrìguez (2014), Absorbing EU ETS windfall profits and the principle of free allowances: Iberdrola and others, cit., pp. 681-682, where it is provided a description of the facts of the case with reference to the granting to the energy undertakings of the emission rights: "the facts of the case relate, in particular, to the Spanish electricity generation sector in EU ETS Phase I, a moment where Member States were obliged by EU law to grant at least 95 percent of the allowances for free in their National Allocation Plans.9 Even though every company in the Spanish power sector received all the allowances allocated to them for free, the electricity undertakings decided to internalize the value of the allowances in their balances, insofar as the fact of submitting the allowances for EU ETS compliance purposes impeded them from selling the allowances to other emitters. As a result of the functioning of the price system in the Spanish electricity market, prices increased for all technologies. Spain considered that such practice amounted to windfall profits in favour of electricity undertakings, because they were charging a higher price to consumers for the value of ETS allowances they had received free of charge or had not even received at all. In order to avoid such undeserved profits, Spain set up a levy 10 equivalent to the surplus revenue obtained by electricity suppliers as a consequence of the integration of the value of the free allowances in their costs. The levy applied to all installations in the ordinary regime, thus excluding renewable energies and co-generation."

${ }^{11}$ Proceeding of the Court of Justice, cases C-566/11, C-567/11, C-580/11, C-591/11, C-620/11, C-640/11, § 42. In the same terms see also $\S \S 43$ segg.

${ }^{12}$ See D. Stevanato (2015), Robin Hood Tax tra incostituzionalità e aperture della Corte a discriminazioni qualitative dei redditi societari, cit., $\mathrm{p}$. 953.

${ }^{13}$ Art. 81, paragraph 1 of the Italian Constitution states: "The State ensures the balance between revenue and expenditure of the budget, taking into account the adverse and favorable phases of the economic cycle."

${ }^{14}$ For an account of this issue see G. Fransoni (2015), L'efficacia nel tempo della declaratoria di incostituzionalità della 'Robin Hood Tax', in Corr. trib., pp. 967 ss.

${ }^{15}$ It should, however, be noted that the Constitutional Court has explicitly dismissed in a recent judgment of October 19, 2016, n. 275 (§§ 11-14) the reasoning put forward in the previous Robin-tax case. In particular, the Court highlighted that the newly introduced art. 81 of the Constitution should not be considered as a provision that attributes constitutional value to budgetary concerns in a way that requires the balancing of such principle with other constitutional values: "non può nemmeno essere condiviso l'argomento secondo cui, ove la disposizione impugnata non contenesse il limite delle somme iscritte in bilancio, la norma violerebbe l'art. 81 Cost. per carenza di copertura finanziaria. A parte il fatto che, una volta normativamente identificato, il nucleo invalicabile di garanzie minime per rendere effettivo il diritto allo studio e all'educazione degli alunni disabili non può essere finanziariamente condizionato in termini assoluti e generali, è di tutta evidenza che la pretesa violazione dell'art. 81 Cost. è frutto di una visione non corretta del concetto di equilibrio del bilancio, sia con riguardo alla Regione che alla Provincia cofinanziatrice. È la garanzia dei diritti incomprimibili ad incidere sul bilancio, e non l'equilibrio di questo a condizionarne la doverosa erogazione".

${ }^{16}$ For an overview of the debate see: W. Weige (2008). Economics of the Law: A Primer. Routledge, London and New York. For details on this law and economics field, inter alia, see: R. Posner (1987). The Constitution as an Economic Document. George Washington Law Review 56(4), pp. 4-38; R. D. Cooter (1999). The Strategic Constitution, Princeton University Press, Princeton, NJ; A. Van Aaken Aaken (2008). How to Do Constitutional Law and Economics: A Methodological Proposal. In: Thomas Eger, Jochen Bigus, Claus Ott, Georgvon Wangenheim (eds.), Internationalization of the Law and its Economic Analysis, Festschrift für Hans-Bernd Schäfer sum 65. Geburtstag. Wiesbaden: Gabler 2008, pp. 651-665.

${ }^{17}$ Posner (1987), p. 5. In the US two important journals have constantly followed the evolution of such new judicial doctrine, where constitutional issues are examined under the law \& economics framework. We refer in particular to the 'The Supreme Court Economic Review', and 'Constitutional Political Economy'.

${ }^{18}$ D. B. Drapkin, P. K. Verleger Jr (1981). The Windfall Profit Tax: Origins, Development Implications, 22 Boston College Law Review 631, p. 633.

${ }^{19}$ Idem, p. 633

${ }^{20}$ J. Taylor, P. Van Doren (2006). Economic Amnesia: The Case against Oil Price Controls and Windfall Profit Taxes. Cato Institute Policy Analysis 561, January 1, p. 1.

${ }^{21}$ Idem, p. 12.

${ }^{22}$ S. Lazzari (1990). The Windfall Profit Tax On Crude Oil: Overview of the Issues. CRS Report for Congress, p. 9.

${ }^{23}$ Taylor and Van Doren (2006), p. 1.

${ }^{24}$ For example see: J. A. Pechman (1967). Federal Tax Policy. The Yale Law Journal 76(5), p. 1038. As argued by the author indeed income taxation, as "a major instrument of social and economic policy," has two goals: the equitable distribution of the costs of government and the promotion of economic growth, stability, and efficiency".

${ }^{25}$ Inter alia, see: N. Rao (2013). Taxes and U.S. Oil Production: Evidence from California and the Windfall Profit Tax. NYU Wagner Research Paper No. 2211681; D. B. Drapkin, P. K. Verlerger Jr (1981). The Windfall Profit Tax: Origins, Development Implications. Boston College Law Review 22(4), pp. 633-704; P. K. Verlerger Jr (1980). An Assessment of the Effects of the Windfall Profits Tax on Crude Oil Supply. The Energy Journal 1(4), pp. 41-58.

${ }^{26}$ For details: R. J. Shapiro, N. D. Pham (2005). The Economic Impact a Windfall Profits Tax For Savers and Shareholders. Sonecom, November, p. 3 .

${ }^{27}$ Idem, p. 6 .

${ }^{28}$ Idem, p. 6.

${ }^{29}$ For an assessment of the opportunities costs at stake see: Shapiro, N. D. Pham (2006). The Economic Impact of a Windfall Profits Tax on Federal, State and Local Public Employee Pension Funds. Investors Action Foundation, p. 2.

${ }^{30}$ For details: R. J. Shapiro, N. D. Pham (2005), The Economic Impact of a Windfall Profits Tax For Savers and Shareholders. Sonecom, November, p. 5.

${ }^{31}$ For a thorough explanation of the relationship between the microeconomic analysis of tax law and income redistribution see: D. A.

Weisbach (2002). Taxes and Torts in the Redistribution of Income. University of Chicago Law \& Economics Olin Working Paper (128).

${ }^{32}$ Idem, pp. 4-7. 
${ }^{33}$ See: S. Lazzari (1990). The Windfall Profit Tax on Crude Oil: Overview of These Issues. CSR Report for Congress, September $12, \mathrm{p}$. CRS-4. See also: T. Marciniak (1974). Proposed Response to the Energy Crisis: Windfall Profits Taxation. Notre Dame Law Review 49, p. 873.

${ }^{34}$ Judgment of the Italian Constitutional Court, § 6.5.2: “orbene, a differenza delle ipotesi appena ricordate, le disposizioni censurate nascono e permangono nell'ordinamento senza essere contenute in un arco temporale predeterminato, né il legislatore ha provveduto a corredarle di strumenti atti a verificare il perdurare della congiuntura posta a giustificazione della più severa imposizione. Con l'art. 81, commi 16, 17 e 18, del d.l. n. 112 del 2008, e successive modificazioni, per fronteggiare una congiuntura economica eccezionale si è invece stabilita una imposizione strutturale, da applicarsi a partire dal periodo di imposta 2008, senza limiti di tempo.

Si riscontra, pertanto, un conflitto logico interno alle disposizioni impugnate, le quali, da un lato, intendono ancorare la maggiorazione di aliquota al permanere di una determinata situazione di fatto e, dall'altro, configurano un prelievo strutturale destinato ad operare ben oltre l'orizzonte temporale della peculiare congiuntura."

${ }^{35}$ For details see: R. Mason, M.S. Knoll (2012). What Is Tax Discrimination? The Yale Law Journal 121(5): 1014-1285.

${ }^{36}$ This represents a form of assessment of reasonability and proportionality, which is usually undertaken by the Italian Constitutional Court. For better insights see T. Guarnier (2008), Ragionevolezza, interpretazione e dialogo tra Giudici. Come la Corte risponde alle esigenze di flessibilità dell'ordinamento, in Giur. it., pp. 1105 ss.; L. Paladin (1997), voce Ragionevolezza (principio di), in Enc. dir., Aggiornamento, IV, Milano.

${ }^{37}$ According to Art. 3 of the Italian Constitution it is provided that "è compito della Repubblica rimuovere gli ostacoli di ordine economico e sociale, che, limitando di fatto la libertà e l'eguaglianza dei cittadini, impediscono il pieno sviluppo della persona umana e l'effettiva partecipazione di tutti i lavoratori all'organizzazione politica, economica e sociale del Paese". On the role of fiscal policies for income redistribution and economic equality, among others, see: IMF (2014). Fiscal Policies and Income Inequality. IMF Policy Paper, January 23.

${ }^{38}$ This is supposedly reasonable by looking at the economics of the income levy. As argued by R. J. Shapiro, N. D. Pham (2005), since "oil producers are 'price takers' who sell at world market prices, they must absorb the cost of the new tax and cannot pass it on to consumers. Hence, the tax raises the marginal cost of production, reducing the quantity of production at any given price (p. 6)".

${ }^{39}$ Judgment of the Italian Constitutional Court, § 6.5.3.

${ }^{40}$ Ibidem, § 6.5.3.

${ }^{41}$ M. Kelman (1993). Could Lawyers Stop Recessions? Speculations on Law and Macroeconomics. Stanford Law Review 45(5): $1216-1217$.

${ }^{42}$ Ibidem, p. 1217

${ }^{43}$ Ibidem p. 1217

${ }^{44}$ For example see: R.L. Gordon (1999). Law and Macroeconomics. The Online Encyclopedia of Law and Economics, pp. 660-693, available online at: http:/ / encyclo.findlaw.com/0620book.pdf. See also: B. M. Salama (2012). The Art of Law \& Economics. University of Pittsburgh Law Review 74, pp. 131-177.

${ }^{45}$ See: Salama (2012), pp. 17-18.

${ }^{46} \mathrm{~A}$ powerful example is given by the growing literature on the Outright Monetary Transactions (OMT) proposed by the European Central Bank in 2012 and on the related judgments before the German Constitutional Court (BVerfG, 2 BvR 2728/13 vom 14.01.2014, Rn. (1-24)) and the European Court of Justice (Case C-62/14. Gauweiler and Others). For an example of such literature see: H. Siekmann, V. Wieland (2014). The German Constitutional Court's decision on OMT: Have markets misunderstood? CEPR Policy Insight (74), pp. 1-12.

${ }^{47}$ Salama (2012), p. 18.

${ }^{48}$ For an empirical assessment of the budgetary equilibrium of the Italian government's with respect to the average tax rate and public debt outstanding see: G. D. Legrenzi, C. Milas (2010). Spend-and-Tax Adjustments and the Sustainability of the Government's Inter temporal Budget Constraint. CESifo Working Paper Series (2926).

${ }^{49}$ For a wide discussion upon the micro and macroeconomic foundations of constitutional frameworks, with respect to the EU primary laws, see: K. Tuori, K. Tuori (2014). The Eurozone Crisis. A Constitutional Analysis. Cambridge University Press, pp. 13-60.

${ }^{50}$ U. S. Das, M. Papapioannou, G. Pedras, F. Ahmed, J. Surti (2011). Managing Public Debt and its Financial Stability Implications. In: Sovereign Debt and the Financial Crisis: Will this Time be Different? C. A P. Braga, G. A. Vincelette (eds.). The World Bank, Washington, pp. 364-365.

${ }^{51}$ Idem, p. 365

${ }^{52} I d$. For deeper insights into the relationship between public debt, volatility and financial instability see also: M. Davies, T. Ng (2011). The rise of sovereign credit risk: implications for financial stability. BIS Quarterly Review, September, pp. 59-70.

${ }^{53}$ In particular, article 140(1) of the TFEU requires "the sustainability of the government financial position". This sustainability is considered apparent when the ratio of the planned or actual government deficit to GDP does not exceed 3\% of GDP, unless either the ratio has declined substantially and continuously and reached a level that comes close to the reference value or, alternatively, the excess over the reference value is only exceptional and temporary and the ratio remains close to the reference value. In addition, the ratio of government debt to GDP shall not exceed a $60 \%$ of GDP, unless the ratio is sufficiently diminishing and approaching the reference value at a satisfactory pace.

${ }^{54}$ For a general discussion over the Maastricht Treaty as a EU macroeconomic constitution see again: K. Tuori, K. Tuori (2014), pp. 41-60.

${ }^{55}$ We refer to the excessive deficit procedure (the so-called "corrective arm") laid down in article 126 and in Protocol 12of the Treaty on the Functioning of the European Union (TFEU) for EU member states that do not fulfill the requirements for fiscal discipline.

${ }^{56}$ See: A. Brunila (2012). Fiscal Policy: Coordination, Discipline and Stabilisation. Bank of Finland Working Paper (7), p. 2.

${ }^{57}$ For an overview on such analytical methodology see: E. J. Mishan (1980). How Valid Are Economic Evaluations of Allocative Changes? Journal of Economic Issues 14(1): 143-161. See for further details: E. J. Mishan (1969). Welfare Economics: an Assessment. North-Holland, Amsterdam.

${ }^{58}$ On the issue see for example: B. S. Bernanke (2011). Speech held at the at the Federal Reserve Community Affairs Research Conference held in Arlington, Virginia, 29 April 2011. As argued by the speaker "People who were vulnerable to begin with-those with low incomes, few assets, and less education-have had a more difficult time weathering the financial storm or recovering from setbacks. The same is true for communities that were already relatively poor, with fewer community assets and insufficient drivers of economic growth".

${ }^{59}$ For an interesting digression upon the relationship between income inequality and solidarity in Europe see: M. Paskova, C. Dewilde (2012). Income inequality and solidarity in Europe. Research in Social Stratification and Mobility 30(4), pp. 419-421.

${ }^{60}$ Nowadays there is large consensus among scholars on an existing trade-off between income inequality and economic growth. For a quantitative analysis of the issue, among others, see: F. Cingano (2014). Trends in Income Inequality and its Impact on Economic Growth. OECD Social, Employment and Migration Working Papers (163). Available online at: http://dx.doi.org/10.1787/5jxrjncwxv6j-en.

${ }^{61}$ For a survey on some other judgments recently issued by the Italian Constitutional Court and characterized by a law and economics approach see: A. Petretto (2013). L'analisi economica del diritto in recenti sentenze della corte costituzionale sulle controversie Stato-Regioni. IRIS Università degli Studi di Firenze Working Paper Series - Economics 22. 
${ }^{62}$ There are few cases where the Italian Constitutional Court has undertaken a review of constitutionality that took into account some aspects which could entail macro distributional effects and microeconomic externalities. See, in this regard, the judgments 14/2004 and $77 / 2005$ of the Italian Constitutional Court.

${ }^{63}$ This is particularly true for the Italian situation, where the economic analysis of the law does not usually receive considerable attention in the decisions of domestic courts.

${ }^{64}$ On the issue, in particular, see: The Future of Law and Economics: Essays by Ten Law School Scholars. The University of Chicago Law School. The Record Online (Alumni Magazine), Fall 2011. Available at: http://www.law.uchicago.edu/alumni/magazine/fall11/lawandecon-future. 